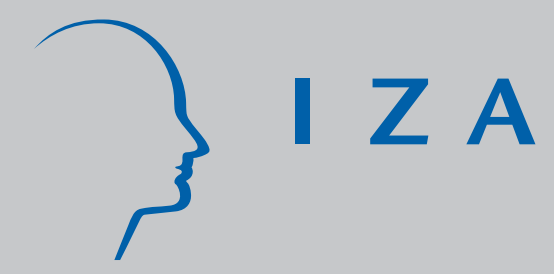

IZA DP No. 2931

Firms and Early Retirement: Offers That One Does Not Refuse

Lutz Bellmann

Florian J anik

July 2007 


\title{
Firms and Early Retirement: Offers That One Does Not Refuse
}

\author{
Lutz Bellmann \\ Institute for Employment Research (IAB), \\ University of Hannover and IZA \\ Florian Janik \\ Institute for Employment Research (IAB)
}

Discussion Paper No. 2931

July 2007

IZA

P.O. Box 7240

53072 Bonn

Germany

Phone: +49-228-3894-0

Fax: +49-228-3894-180

E-mail: iza@iza.org

Any opinions expressed here are those of the author(s) and not those of the institute. Research disseminated by IZA may include views on policy, but the institute itself takes no institutional policy positions.

The Institute for the Study of Labor (IZA) in Bonn is a local and virtual international research center and a place of communication between science, politics and business. IZA is an independent nonprofit company supported by Deutsche Post World Net. The center is associated with the University of Bonn and offers a stimulating research environment through its research networks, research support, and visitors and doctoral programs. IZA engages in (i) original and internationally competitive research in all fields of labor economics, (ii) development of policy concepts, and (iii) dissemination of research results and concepts to the interested public.

IZA Discussion Papers often represent preliminary work and are circulated to encourage discussion. Citation of such a paper should account for its provisional character. A revised version may be available directly from the author. 
IZA Discussion Paper No. 2931

July 2007

\begin{abstract}
Firms and Early Retirement: Offers That One Does Not Refuse

According to the Hutchens (1999) model, early retirement is not explained as a result of maximizing expected individual utility but rather as a demand-side phenomenon arising from a firm's profit-maximizing behaviour. Firms enter into contracts with their employees that include clauses about early retirement. In response to demand or technological shocks, workers receive retirement offers from their employers which cannot be rejected by rational actors. Using the IAB Establishment Panel 2003-2006, the relationship between indicators of demand and technological shocks and the incidence and amount of early retirement is analysed. The results provide general support to the Hutchens model.
\end{abstract}

JEL Classification: J14, J21, J23, J26

Keywords: (involuntary) early retirement, labour demand, panel data

Corresponding author:

Lutz Bellmann

Institut für Arbeitsmarkt- und Berufsforschung (IAB)

Regensburger Str. 104

90478 Nürnberg

Germany

E-mail: lutz.bellmann@iab.de 


\section{Introduction}

Owing to the demographic challenge in Germany as well as in many other countries, retiring before reaching the regular retirement age is of great significance for the labour market. In 2006 the average retirement age for old-age pensions in Germany was 63.2 years according to the Association of German Pension Insurance Institutions (Verband der Deutschen Rentenversicherung). If people who receive a pension due to a reduced ability to work are added to this figure, the average retirement age falls to 60.9 years (Deutsche Rentenversicherung 2007). Many people in Germany therefore take early retirement.

In scientific discourse a large amount of theoretical and empirical work has been conducted to explain early retirement from the labour-supply side ${ }^{1}$. An employee's decision to enter retirement depends on his/her expected future income from wages and private and state pension payments. Employees choose their retirement age so as to maximise their future expected utility. From this theoretical approach it is possible to derive the significance of the way that the pension system is arranged for making decisions about taking retirement: the earlier that retirement is possible and the lower the financial losses are when taking early retirement, the more frequently people will choose this route to pension receipt. Blöndal/Scarpetta (1999) and Duval (2003) confirm this by means of international comparisons. An overview of the situation in Germany is provided by Arnds/Bonin (2002).

The phenomenon of early retirement is rarely discussed in scientific terms from the labour-demand side. This is surprising, since firstly the well-known models by Lazear (1979) and Stern $(1987,1994)$ focus on firms' interest in early retirement, and secondly, older workers are particularly affected by dismissals associated with workforce reductions (Schmähl 2003, Dorn/Souza-Poza 2005).

In the moral hazard model of Lazear (1979), mandatory retirement at a certain point in time plays an important role. Only when such a point in time is laid down before the conclusion of a contract are contracts concluded which pay younger workers a wage below their marginal product and older workers a wage above it (seniority wages). With these considerations, Lazear (1979) thus provides both a supply-side and a 
demand-side explanation for a mandatory retirement time. Stern $(1987,1994)$ shows that firms can also be interested in parting with employees when their productivity is higher than their wage. Here she assumes that employees' utility and productivity both depend on the wage paid and the position reached within the firm. In addition, productivity is determined by occupational experience. Under these conditions it can be profitable for the firm to shed older workers before they reach the regular retirement age and to replace them with younger workers. In this case the firm calculates the lower costs for the younger workers against the additional costs for new hirings and the costs of dismissing the older workers. The wage costs for the younger workers are lower since they have less experience. Furthermore, the departure of the older workers frees up places in the company hierarchy, which then, when the places are filled by younger workers, raises the workers' utility without increasing the wage costs. Both of the authors therefore provide arguments in favour of examining not only the labour-supply side in the issue of early retirement, but also the labour-demand side.

Desmet/Jousten/Perelman (2005) recently pointed out that when examining unemployment it is important to distinguish between "voluntary" and "involuntary" (early) retirement. Smith (2006) reports that consumption only falls in the case of people who retire early involuntarily (in other words induced by the employer). In spite of this differentiation, which is being increasingly recognised as significant, the empirical findings about early retirement as a result of labour-demand processes are rare and generally of qualitative nature. For Germany Schmähl (2003) provides an overview of these studies and presents as the joint result the fact that the dismissal of older workers is the most commonly used strategy to deal with staffing problems associated with company restructuring measures. Firms can therefore use early retirement as a way to adjust the workforce if staff cuts are needed in the firm. Furthermore in this way it is possible to organise an exchange of staff which appears necessary because the qualifications and skills available in the firm no longer match the requirements which are changing due to technological innovations. If early retirement and the re-filling of the jobs is cheaper than providing the workers with further training, firms will also make use of this possibility. In a case study, Teipen (2003) distinguishes between three strategies used by firms in connection with early retirement. In the consensus model, early retirement is part of a long-term personnel 
policy negotiated between the employer and the works council and is a strong component of the firm's social policy. The age limit is set in such a way as to enable the firm to make necessary staff cuts and thus to guarantee job security for the rest of the workforce. In the conflict model early retirement is used as an instrument for shedding labour above all in the context of existing institutional regulations. This does not lead to job security for the remaining staff, however. The third case describes firms which only use early retirement in individual cases, either because large-scale adjustments in the workforce are not necessary or because alternative adjustment potentials exist. Aleksandrowicz (2006) points out, however, that it is sometimes difficult to identify a clear early retirement strategy in firms since in some cases existing routes to early retirement are being reduced and at the same time new ones are being introduced, often with reference to the expected lack of skilled labour.

In an international context, too, there are only few, generally qualitative, studies that examine early retirement empirically from the viewpoint of the labour-demand side (Lumbsdaine/Mitchell 1999). Hutchens (1999) develops a model that is based on implicit contracts in which early retirement occurs as a result of firms' profit maximisation. In this model, too, favourable institutional early retirement provisions lead to an increase in early retirement. This does not occur at the employee's request, however, but on the initiative of the (profit-maximising) firm. Here the pension system acts as a kind of unemployment insurance which reduces the dismissal costs for the firms. Dorn/Sousa-Poza $(2005,2007)$ use data from the International Social Survey Program (ISSP) to examine involuntary early retirement in 19 OECD countries against the background of Hutchens' (1999) model. They find connections between macroeconomic indicators and the institutional regulations, which indicate that in times of crisis firms push some of their workforce into early retirement. Using survey data from the USA, Hutchens (2007) finds that employers actively offer their employees progressive retirement, but that they do so selectively. In particular older skilled workers have a greater chance of receiving an offer of progressive retirement.

The model by Hutchens (1999) is also used in the following to examine the phenomenon of early retirement as a consequence of firms' profit calculation. The paper is structured as follows: in chapter 2 the theoretical model is presented. In the 
third chapter the data set used and the empirical procedure are explained. In the fourth part the results are presented. The fifth and final part summarises the findings.

\section{Early retirement as a consequence of decisions made by firms}

In contrast to the approaches that look solely at the labour-supply side, the Hutchens (1999) model does not focus on the employees' behaviour but on that of the employer. The model of early retirement, which was developed against the background of the theory about implicit contracts, starts out from two actors: a riskneutral firm and a risk-averse worker. The firm is faced with the problem of offering the worker a contract which on the one hand maximises profit and on the other hand does not put the worker in a worse position than he would be in a contract with another potential employer, because otherwise the worker would leave the firm.

The contract is concluded for three periods ${ }^{2}$. In the first period the worker is permanently employed and in the third period permanently retired. However, the worker only survives until entry in the retirement phase with the probability $s$. When the contract is concluded it is uncertain whether the worker will still be in the firm in the second phase or will already be in early retirement. Applied to the German situation, workers are under the age of about 50 in the first period, between 50 and about 65 in the second period, and over the age of approximately 65 in the third period. Technological shocks or a drop in demand can reduce the worker's marginal product at the same time as the worker's utility from home work ${ }^{3}$ increases. In this context, early retirement can be a rational response to the events in the second phase. The firm concludes the employment contract in such a way that profit maximisation is guaranteed both in the case of early retirement and in the case of continued employment. The firm undertakes to employ the worker in the first period, either to employ him or to pay him a private pension $b_{i}$ in the second period and also to pay a private pension $b_{i}$ in the third period if the worker reaches this period. The worker agrees to such a contract because he is interested in having steady consumption throughout his life. This aim is achieved because he protects himself in this way from a loss of income in the second period, which would occur if his marginal product fell due to a shock and he became unemployed as a result. 
The worker's expected utility is composed of the individual utilities of the three periods ${ }^{4}$. If the worker is employed, his utility $U\left(w_{i}\right)$ is determined above all by the wage $w_{i}$ paid in the period $i$. If the worker retires, his utility is composed of the income from the private pension contract agreed with the firm $b_{i}$, the payments from the state pension system $g_{i}$ and the utility of home work $z_{i}: U\left(b_{i}+g_{i}+z_{i}\right)$. Furthermore $z_{1}=0, z_{3}=z_{\max }$ and $0 \leq z_{2} \leq z_{\max }$ apply. It has to be taken into account here, however, that the value of $z_{2}$ is unknown to both parties at the time when the contract is concluded and only becomes known at the start of the second period. If the worker retires in the third period, he receives the full pension $g_{3}$ in this period. In the case of early retirement in the second period the worker receives the pension $g_{2}$ in the second and the third periods. In this case, however, pension deductions $\Delta$ are made. $g_{2}=g_{3}-\Delta$ holds.

If $p$ denotes the probability of the worker being employed in the second period and $b_{3}^{1}$ and $b_{3}^{0}$ denote the utility of the private pension depending on the employment status in the second period, the worker's expected utility $E U$ in the three periods can be determined as follows (Hutchens 1999):

(1.1) $E U=\sum_{i=1}^{3} E U_{i}$

(1.2) $E U_{1}=U\left(w_{1}\right)$

(1.3) $E U_{2}=0,5 \sum_{\theta_{2}=\theta(L)}^{\theta_{H}} \int_{Z}\left\{p\left(\theta_{2}, z_{2}\right) U\left[w_{2}\left(\theta_{2}, p_{2}\right)\right]+\left[1-p\left(\theta_{2}, z_{2}\right)\right] U\left[b\left(\theta_{2}, z_{2}\right)+g_{2}+z_{2}\right]\right\} f\left(z_{2}\right) d z_{2}$

(1.4) $E U_{3}=0,5 \sum_{\theta_{2}=\theta(L)}^{\theta_{H}} s \int_{z}\left\{p\left(\theta_{2}, z_{2}\right) U\left[b_{3}^{1}+g_{2}+\Delta+z_{\max }\right]+\left[1-p\left(\theta_{2}, z_{2}\right)\right] U\left[b_{3}^{0}+g_{2}+z_{\max }\right]\right\} f\left(z_{2}\right) d z_{2}$

The utility in the second and third periods, for which the employment status is unknown to both parties at the time when the contract is concluded, is depicted here with integrals that are weighted by their probability of occurrence. In the classical labour-supply analysis of entry into retirement, the worker opts, with a given wage and private and state pension payments, for a value $p$, which maximises his expected utility. He therefore decides whether or not to retire already in the second period. However, in the Hutchens (1999) model, the probability of being employed in the second period $p$ results from the behaviour of the firms, which is oriented 
towards profit maximisation. Whether the worker is employed in the second period thus depends on the one hand on the agreed wage and pension payments and on the other hand on the marginal product gained from the work in the second period and the utility from the home work. The firm's profit can be determined in each period as the difference between the costs incurred by paying the wage and the pension and the worker's output. The marginal product of the work is $\theta(H)$ in the first and $\theta(L)$ in the last period and $\theta(H)>\theta(L) \geq 0$ and $\theta(L)<z_{\max }$ apply. The marginal product in the second period on the other hand is unknown when the contract is concluded and becomes known to both parties simultaneously with $z_{2}$. The value of $\theta_{2}$ depends on the demand for the goods and services produced, on the technology used and thus indirectly also on the workers' skill level. In the case of a shock which affects these aspects, the marginal product in the second period is $\theta(L)$, and $\theta(H)$ if such a shock does not occur. For simplification purposes it is assumed that the probability of such an event occuring is 0.5 .

The firm's expected profit $\pi$ can therefore be expressed as follows (Hutchens 1999):

(2.1) $\pi=\sum_{i=1}^{3} \pi_{i}$

(2.2) $\pi_{1}=\theta_{1}(H)-w_{1}$

(2.3) $\pi_{2}=0,5 \sum_{\theta_{2}=\theta(L)}^{\theta(H)} \int_{z}\left\{\left[\theta_{2}-w\left(\theta_{2}, z_{2}\right)\right] p\left(\theta_{2}, z_{2}\right)-b\left(\theta_{2}, z_{2}\right)\left[1-p\left(\theta_{2}, z_{2}\right)\right]\right\} f\left(z_{2}\right) d z_{2}$

(2.4) $\pi_{3}=0,5 \sum_{\theta_{2}=\theta(L)}^{\theta(H)} s \int_{z}\left\{-p\left(\theta_{2}, z_{2}\right) b_{3}^{1}-\left[1-p\left(\theta_{2}, z_{2}\right)\right] b_{3}^{0}\right\} f\left(z_{2}\right) d z$

The worker and the employer negotiate a contract that covers all three periods and includes the respective wages and the private pension. The firm chooses the variables $w_{1}, w\left(\theta_{2}, z_{2}\right), p\left(\theta_{2}, z_{2}\right), b\left(\theta_{2}, z_{2}\right)$ and $b_{3}$, thereby maximising its profit. The worker's utility and the employer's profit are therefore not examined individually in each period, but across the three phases, in other words intertemporally and optimised, though individual parameters $\left(\theta_{2}, z_{2}\right)$ are unknown to both parties at the time when the contract is concluded. Here the worker's expected utility throughout the entire period of the contract must not fall short of the exogenous utility from a different employment relationship on the market. Hutchens (1999) shows that under these conditions the employee's status in the second period can be described by the 
following decision rule:

The workers is also employed in the second period $\left(p\left(\theta_{2}, z_{2}\right)=1\right)$, if

(3.1) $\theta_{2} \geq z_{2}+g_{2}-\Delta s$

applies.

The worker goes into early retirement $\left(p\left(\theta_{2}, z_{2}\right)=0\right)$, if

(3.2) $\theta_{2}<z_{2}+g_{2}-\Delta s$

applies.

If the worker's marginal product in the second period is greater than the marginal value on the right-hand side of the equation, the employment relationship will be continued. However, if due to a demand-induced or technological shock the worker is no longer productive enough, early retirement brings the worker at least the same utility as continued employment. What must be taken into account is that the early retirement in this model does not depend on the level of the state pension payments in the third period, nor on the private pension payments or the wages, but solely on $\theta_{2}$ and $z_{2}$ under the condition of the firm's profit maximisation. The firm therefore plays an active role in the early retirement. The wages and the private pension are set in such a way that the two alternatives, working or retiring early, have the same utility for the worker. Nonetheless this possibility of early retirement, which is regarded as voluntary when the contract is concluded, may be perceived by the worker as involuntary at the actual time of retirement (Dorn/Souza-Poza 2005).

Some conclusions result from this model with regard to the incidence and the extent of early retirement (Hutchens 1999, Dorn/Souza-Poza 2005):

1. Higher state pension payments in the second period and a smaller pension reduction in the case of early retirement lead to more cases of early retirement.

2. In countries with more stringent employment protection legislation, early retirement is more likely to be used as it is more difficult to use dismissals for personnel policy purposes.

3. Demand shocks and technological innovations and the associated skills requirements lead to a firm offering workers early retirement since such shocks lower the workers' marginal product $\theta_{2}$.

Whereas the analysis conducted by Dorn/Souza-Poza (2005) is based on individual 
data and the international comparison included in the analysis is oriented strongly towards the second conclusion, this paper focuses on the third aspect. As the change in the productivity of the work over time and in the utility of the home work are very difficult or impossible to observe, German establishment data are used to examine whether the theoretical relationship between indicators of technological and demand-induced shocks and the incidence and extent of early retirement can also be proven empirically and thus whether the firm can be regarded as an actor in the decision regarding entry into retirement.

\section{Data, hypotheses and variables}

The basis for the following empirical analysis is the IAB establishment panel. This is a survey which has been conducted annually since 1993 in western Germany and since 1996 in eastern Germany, generally using oral interviews. The population covers all establishments which have at least one employee subject to social security contributions ${ }^{5}$.

In the IAB establishment panel questions are regularly asked as to whether any employees left the firm in the first six months of the year of the respective survey wave, and if so, how many. In addition the replies are differentiated according to the particular reason for leaving. Since 2003 this has also included the category "retirement before reaching the regular (statutory) retirement age". This is used as the dependent variable in the following analyses. The variable used is problematic in two respects but has to be used here for lack of any alternatives. The first problem is that it is not possible to distinguish between employee-induced and employerinduced early retirement. Dorn/Sousa-Poza (2005) report that in Germany only half of all cases of early retirement are classed as involuntary by the workers concerned. Secondly, Bielenski/Ullmann (2005) pointed out that there is a difference between the reason for terminating a contract and the legal arrangement, which can lead to distorted information in both individual and firm surveys. For example, employers and workers can agree to terminate an employment relationship by the employer giving notice in order to prevent the worker losing unemployment benefit. It can therefore occur that the respondents report a termination by the employer as "consensual" or as "transition into retirement" although it is actually a dismissal. Owing to these restrictions as regards the dependent variable, the empirical analysis can only be 
used to determine whether firm characteristics play a role in early retirement and not to determine the extent to which this occurs.

A balanced panel is used for the analysis, i.e. all of the firms that took part in the survey without interruption between 2003 and 2006 are included in the analysis. Firms in public administration and non-profit firms are not taken into account as the assumption of profit maximisation is not tenable in these firms. The study is also restricted to western Germany as a result of the highly different labour market situation in the two parts of Germany.

[Insert Table 1 here]

In the following the variables used and their assumed correlations with the incidence and extent of early retirement are described (cf. also Table 1). Hutchens (1999) cites technological and demand-induced shocks as the reason for the decrease in the workers' marginal productivity, which subsequently leads to cases of early retirement.

The economic situation of the firm, which is closely related to the demand situation, is portrayed by different variables. In accordance with the theory it is assumed that employment growth in a firm is negatively correlated with the incidence and intensity of early retirement. A dummy indicates whether the profit situation of the firm was sufficient or insufficient in the last business year. As a negative profit situation can be the result of a demand shock, a positive correlation with early retirement is expected.

A technological shock as a reason for early retirements is depicted by two variables. A large amount of investment per employee should correlate positively with early retirement as it can be assumed that this is also accompanied by changes in the skill demands, especially when investment is made in more modern plant and new technology. A technological shock can, however, also lead to the firm having to part company with some of its workers in order to replace them with other better qualified workers. A measure for the turnover of employment relationships is the so-called churning rate $^{6}(\mathrm{CR})$, which describes the part of the labour mobility that can not be explained by the change in the number of employees in the firm. It is calculated as follows: 


$$
C R=(H+S-|H-S|) / L,
$$

where $\mathrm{H}$ stands for the number of hirings, $\mathrm{S}$ for the number of employees leaving and $L$ for the average number of employees in the observation period. These are expected to be positively correlated with the incidence of early retirement ${ }^{7}$.

Schmähl (2003) reports about various qualitative studies in which early retirements are also accompanied by company-internal measures to increase flexibility. The share of part-time employees and whether overtime ${ }^{8}$ is worked in the firm are therefore included as control variables. In each case a positive correlation with the dependent variables is assumed.

Industrial relations also play a significant role in the arrangement of early retirement provisions (Schmähl 2003). In the consensus model described by Teipen (2003), early retirement is part of a long-term personnel policy negotiated between the employer and the works council and is a fixed component of the firm's social policy. Works councils strengthen the bargaining position of the workforce when a firm is undergoing restructuring. This also has consequences on the firm's early retirement strategy. In addition, some collective agreements contain explicit regulations concerning progressive retirement and early retirement. Two dummies therefore control for whether there is a works council in the firm and whether the firm has collective agreements. These two variables are also expected to have a positive correlation with cases of early retirement.

As Teipen (2003) reports that especially limited companies use early retirement as a conflict-free way to reduce the workforce, a corresponding dummy is included. Pfarr et al. (2005) and Jahn (2005) refer to the relationship between the termination of contracts, early retirement and the existence of a social plan. Social plans are obligatory in firms with a works council when mass dismissals are being conducted. Schmähl (2003), too, refers to the relationship between agreements to terminate contracts and early retirement. Another dummy therefore indicates whether employment contracts are terminated consensually in a firm. It is assumed that in firms which terminate contracts in a consensual way there are often social plans which also encourage early retirements. 
Two dummies indicate whether parts of the firms were closed down, spun off or hived off or whether insourcing occurred during the observation period. Both of these variables can have an effect on a firm's demand for labour and thus also on the incidence of early retirement. The direction of the expected correlation is not clear, however. In addition, firm size is included as a logarithm. As smaller firms tend to adjust their staffing levels more rapidly and have fewer financial resources at their disposal and since fewer employment protection regulations have to be taken into account in small firms, increasing firm size can be expected to be associated with increasing early retirement (Schmähl 2003). As the firms to be interviewed in the IAB establishment panel are selected using stratified random sampling (Bellmann 2002), the stratification variables should be controlled for according to DuMouchel/Duncan (1983) and Winship/Radbill (1994). For this reason eight dummies for industry affiliation are included besides the firm size.

The empirical analysis is conducted in two steps. First, fixed-effects (FE) and random-effects (RE) logit and probit estimators are used to examine the incidence of early retirement. In the second step the extent of early retirement is examined. As the dependent variable used here, the number of cases of early retirement, takes on integer values greater than or equal to zero, the use of a count data model presents itself (fixed-effects and random-effects negative binomial regression) (Hausman/Hall/Griliches 1984). In practice, least squares estimates are frequently carried out for such cases, but this can lead to inefficient, inconsistent and biased estimates. For example, conventional estimates can yield negative or non-integer estimate results (cf. Long/Freese 2003: 245). With the FE estimates, the influences of time-invariant firm-specific characteristics are eliminated and only the influence of dependent variables that change over time is observed. As a number of theoretically influential variables (e.g. works council, collective agreements) hardly vary over time, however, and the four-year observation period is not particularly long, the analysis is supplemented by the RE estimates, which also take into account firm-specific characteristics that remain constant over time. If the RE results differ from the $F E$ results, which is also tested using a Hausman test in the logit estimates, reference is made to this in the interpretation. 


\section{Results and interpretation}

The results of the logit and probit models can be found in table 2 and those of the NBReg estimates in table 3 . The negative significant coefficient of the rate of employment growth in all of the estimates confirms the expected influence of demand shocks on the incidence and the extent of early retirement. This also holds for the positive significant correlation between the churning rate and early retirement. The significance of technological shocks is therefore also confirmed since it can be assumed that a higher level of staff turnover also indicates a skills mismatch in the firm. The positive significant coefficients of the amount of investment in the RE estimates additionally support the significance of this argument. The variables that are intended to measure company-internal instruments to increase flexibility do not possess the expected explanatory contribution and the share of part-time employees even has the opposing explanatory contribution. The reason why the expected positive influence on the incidence of early retirement fails to emerge may be because these instruments to increase flexibility can also have different motivations than technological or demand-side shocks. Overtime, for example, can be a response to an increase in the order situation in which the existing staff is not sufficient to deal with the amount of work arising. Accordingly, in such a situation a firm is more likely to oppose its employees retiring early. In contrast, part-time work can be attributed not only to the firm's needs but also to the workers' wishes or needs. Especially in the case of part-time work due to bringing up children, employment relationships may be anything but flexible from the point of view of the firms. The expected positive correlation between the size of a firm and the incidence of early retirement and the number of cases of early retirement is confirmed, therefore also confirming the thesis reported by Schmähl (2003) that small firms are able to use other possibilities of workforce adjustment. The importance of industrial relations for early retirement, which was emphasised in particular by Teipen (2003), is only confirmed in the RE estimates. In firms which have collective agreements and firms with a works council, early retirement nonetheless occurs more frequently and to a larger extent. The expected correlation between the existence of agreements to terminate contracts and cases of early retirement is also confirmed. What is not in line with the findings obtained by Teipen (2003) is the finding that limited companies use early retirement more rarely and to a lesser extent than other firms. 
[Insert Tables 2 and 3 here]

What is also striking for all of the estimates is the fact the closeness of fit takes on only very low values. So although it is possible to ascertain an influence of the described variables on early retirement, only a comparatively small part of the extent and in particular of the incidence is explained by the estimate. This can be explained on the one hand by the dependent variable used. As explained earlier, it measures both employee-induced and employer-induced cases of early retirement and is used as an indicator of employer-induced early retirement here only for lack of any alternatives. On the other hand this can also be interpreted as support of the considerations made by Aleksandrowicz (2006), who points out that it may be difficult in certain circumstances to identify a clear early retirement strategy in firms as in some cases existing early retirement methods are being reduced, often with reference to the expected lack of skilled labour, and at the same time new methods are being opened up.

Nevertheless the results can be regarded as confirming the Hutchens (1999) model. Indicators of demand shocks and technological shocks and the response of the profit-maximising firms to such shocks have an effect on the incidence and extent of early retirement. It is therefore necessary to take into account not only the workers but also the firms as actors in the discussion about entry into early retirement, especially when the cases of early retirement are accompanied by company-internal restructuring measures as a result of technological changes or by workforce reductions as a result of demand-induced shocks.

\section{Summary}

Premature withdrawal from working life and the transition into early retirement is often discussed and analysed from the employee side. A worker's decision to retire depends on his expected future income from wages and from private and state pension payments. In these models the worker chooses his retirement age in such a way as to maximise his future expected utility. The role of the employer in this context has rarely been the focus of scientific analysis to date, however, although in media 
debates a connection is frequently established between reactions of firms and early retirement (Hutchens 1999). On the basis of the Hutchens (1999) model, this paper analyses early retirement as a consequence of firms' profit-maximising behaviour. The firms enter into contracts with their workers which enable them, in the case of technological or demand-induced shocks, to make their workers an offer of early retirement which is not refused by rational actors. The relationship that follows from this model between indicators of technological and demand-induced shocks and the incidence and extent of early retirement is tested using data from the IAB establishment panel 2003-2006. The results confirm the relationship postulated by Hutchens. In addition to this, the quantitative analysis also confirms a number of findings from qualitative studies. Thus for instance, positive correlations are found between firm size and industrial relations (collective agreements and the existence of a works council) and the occurrence of consensual termination of contracts in the context of social plans with entry into early retirement. What is not confirmed, however, is the finding by Teipen (20203) that limited companies use early retirement to a larger extent. This must be qualified by saying that the explanatory power of the estimates is only relatively small. This can be put down firstly to the dependent variable used, which measures both employer-induced and employee-induced early retirement; secondly it can also be interpreted as an indication that it may be difficult in certain circumstances to identify a clear early retirement strategy in firms, as in some cases existing early retirement methods are being reduced and at the same time new methods are being introduced (Aleksandrowicz 2006).

Nonetheless the results indicate that in the political and scientific debate surrounding early retirement it is necessary to view the firms increasingly as actors. 


\section{References}

Alda, H./Allaart, P./Bellmann, L. (2005): Churning and institutions. Dutch and German establishments compared with micro-level data. IAB Discussion Paper 12/2005.

Aleksandrowicz, P. (2006): The interplay of retirement policy and externalisation strategies towards older workers in Polish and German enterprises. ZeSArbeitspapier 1/2006.

Arnds, P./Bonin, H. (2002): Frühverrentung in Deutschland: Ökonomische Anreize und institutionelle Strukturen. IZA Discussion Paper 666.

Bellmann, L. (2002): Das IAB-Betriebspanel. Konzeption und Anwendungsbereiche. In: Allgemeines Statistisches Archiv 86(2), 177-188.

Bielenski, H./Ullmann, K. (2005): Arbeitgeberkündigungen und Klagequote. In: Bundesarbeitsblatt 10(1), 4-13.

Blöndal, S./Scarpetta, S. (1998): The retirement decision in OECD countries. OECD Economics Department Working Papers 1998(15). Paris: OECD.

Boockmann, B./Hagen, T. (2002): Arbeitsplatzdynamik und befristete Verträge: Empirische Evidenz aus dem IAB-Betriebspanel für Baden-Württemberg. In: Mitteilungen aus der Arbeitsmarkt- und Berufsforschung 35(3), 385-396.

Desmet, R./Jousten, A./Perelman, S. (2005): The benefits of separating early retirement from the unemployed: Simulation results from Belgian wage earners. CEPR Discussion Paper 5077.

Deutsche Rentenversicherung (2007): Rentenversicherung in Zahlen 2007 - Statistik der Deutschen Rentenversicherung. Berlin.

Dorn, D./Sousa-Poza, A. (2005): Early retirement: Free choice or forced decision? CESIFO Working Paper 1542.

Dorn, D./Souza-Poza, A. (2007): 'Voluntary' and 'involuntary' early retirement: An international analysis. IZA Discussion Paper 2714.

DuMouchel, W. H./ Duncan, G. J. (1983): Using sample survey weights in multiple regression analysis of stratified samples. In: Journal of the American Statistical Association 78, 535-543.

Duval, R. (2003): The retirement effects of old-age pension and early retirement schemes in OECD countries. OECD Economics Department Working Papers 2003(24). Paris: OECD.

Hausman, J./ Hall, B. H./ Griliches, Z. (1984): Econometric models for count data with an application to the patents - R \& D relationship. In: Econometrica 52, 909-938. 
Hutchens, R. (1999): Social security benefits and employer behaviour: Evaluating social security early retirement benefits as a form of unemployment insurance. International Economic Review 40(3), 659-678.

Hutchens, R. (2007): Worker characteristics, job characteristics and opportunities for phased retirement. IZA Discussion Paper 2564.

Jahn, E. (2005): Wie wirkt der Kündigungsschutz? In: Zeitschrift für Arbeitsmarktforschung 38(2+3), 284-304.

Lazear, E. P. (1979): Why is there mandatory retirement? In: Journal of Political Economy 87(6), 1261-1284.

Long, J.S./Freese, J. (2003): Regression Models für categorical dependent variables using STATA. College Station: Stata Press.

Lumsdaine, R./Mitchell, O. (1999): New developments in the economic analysis of retirement. In: Ashenfelter, O./ Card, D. (Hrsg.): Handbook of Labor Economics. Volume 3C. Elsevier, 3261-3307.

Pfarr, H./Ullmann, K./Bradtke, M./Schneider, J./Kimmich, M./Bothfeld, S. (2005): Der Kündigungsschutz zwischen Wahrnehmung und Wirklichkeit: Betriebliche Erfahrungen mit der Beendigung von Arbeitsverhältnissen. München und Mering: Rainer Hampp.

Schmähl, W. (2003): Ageing workforce: Firm strategies and public policy in Germany: In: Geneva Papers on Risk and Insurance 28, 575-595.

Smith, S. (2006): The retirement-consumption puzzle and involuntary retirement: Evidence from the British household panel survey. In: The Economic Journal 116, C130-C148.

Stern, S. (1987): Promotion and optimal retirement. In: Journal of Labor Economics 5(4), 107-123.

Stern, S. (1994): Ability, promotion and optimal retirement. In: Journal of Labor Economics 12(1), 119-137.

Teipen, C. (2003): Die Frühverrentung im Wandel betrieblicher Strategien. München und Mering: Rainer Hampp.

Winship, C./ Radbill, L. (1994): Sampling weights and regression analysis. In: Sociological Methods and Research 23, 230-257.

\footnotetext{
${ }^{1}$ An overview of these approaches and the empirical results is provided by Lumsdaine/Mitchell (1999).

${ }^{2}$ Staff departures before entry into the second period as a result of notice given by the employer or the employee are thus not taken into account in the model. As early retirement is only possible for workers who have reached at least the second phase in the firm, however, this seems to be an acceptable simplification.

${ }^{3}$ Home work is to be understood in a very broad sense here. The increase in utility as a result of leisure time, such as from long holidays, is also included here.
} 
${ }^{4}$ For simplification purposes we dispense with discounting.

${ }^{5}$ For further information about the IAB establishment panel see Bellmann (2002).

${ }^{6}$ There are several measurement concepts for the churning rate (cf. Boockmann/Haagen 2002: 387). The churning rate used here is calculated in the same way as in Alda/Allaart/Bellmann (2005).

${ }^{7}$ A causality problem is conceivable at this point, since people leaving the firm due to early retirement also flow into the churning rate. However, as only about $4 \%$ of the people leaving firms in the IAB establishment panel are cases of early retirement, this can be ignored here.

${ }^{8}$ Information about overtime hours worked is only available in the IAB establishment panel in 2004 and 2006. For the estimate it is assumed that if overtime was worked in a firm in 2004 and 2006 it also occurred in the respective previous years. 


\section{Appendix}

Table A: Description of variables

\begin{tabular}{lrr}
\hline Variable & $\bar{x}$ & $s$ \\
\hline Early retirement dummy & 0.0882 & 0.2835 \\
\hline Number of cases of early retirement & 0.4917 & 3.6342 \\
\hline Rate of employment growth & -0.0123 & 0.1842 \\
\hline Low profit situation (dummy) & 0.3592 & 0.4798 \\
\hline Amount of investment (In) & 5.4173 & 3.8704 \\
\hline Churning rate & 0.0387 & 0.1066 \\
\hline Share of part-time employees & 0.1993 & 0.2278 \\
\hline Overtime (dummy) & 0.6511 & 0.4766 \\
\hline Collective agreements (dummy) & 0.5614 & 0.4962 \\
\hline Works council (dummy) & 0.3019 & 0.4591 \\
\hline New operating units incorporated (dummy) & 0.0239 & 0.1529 \\
\hline Operating units have been spun off / hived off / closed (dummy) & 0.0377 & 0.1906 \\
\hline Consensual termination of employment relationships (dummy) & 0.0926 & 0.2899 \\
\hline Limited company (dummy) & 0.5728 & 0.4947 \\
\hline Firm size (ln) & 3.3860 & 1.6709 \\
\hline Industry dummies $\quad$ Agriculture and forestry & & \\
\hline & 0.0250 & 0.1563 \\
\hline$\quad$ Mining & 0.0230 & 0.1499 \\
\hline$\quad$ Manufacturing & 0.2948 & 0.4560 \\
\hline$\quad$ Construction & 0.1002 & 0.3002 \\
\hline$\quad$ Wholesale and retail trade and repairs & 0.1783 & 0.3828 \\
\hline$\quad$ Transport, storage and communication & 0.0399 & 0.1958 \\
\hline$\quad$ Financial intermediation & 0.0416 & 0.1997 \\
\hline$\quad$ Business services & 0.1560 & 0.3629 \\
\hline$\quad$ Other services & 0.1411 & 0.3482 \\
\hline \hline & & \\
\hline $\mathrm{N} \quad$ & 11820 & \\
\hline $\mathrm{n}$ & 2955 & \\
\hline
\end{tabular}

Source: IAB establishment panel 2003-2006, own calculations 
Table 1: Expected correlations

Variable

Expected correlations

Rate of employment growth

Low profit situation (dummy)

Amount of investment (In)

Churning rate

Share of part-time employees

Overtime (dummy)

Collective agreements (dummy)

Works council (dummy)

New operating units incorporated (dummy)

Operating units have been spun off / hived off / closed (dummy)

Consensual termination of employment relationships (dummy)

Limited company (dummy)

Firm size (In)

Industry dummies

$+$

$+$

$+$

$+$

$+$

$+$

$+$

$+$

$+1-$

$+1-$

$+$

$+$

$+$

+


Table 2: Estimate results for the incidence of early retirement in the firm, FE logit, RE logit, RE probit

\begin{tabular}{|c|c|c|c|}
\hline Variable & FE logit & RE logit & RE probit \\
\hline \multirow[t]{2}{*}{ Rate of employment growth } & $-2.120^{\star \star \star \star}$ & $-1.550 * \star \star$ & $-0.880^{* \star \star \star}$ \\
\hline & $(3.63)$ & $(4.24)$ & $(4.70)$ \\
\hline \multirow[t]{2}{*}{ Low profit situation (dummy) } & -0.063 & -0.026 & -0.006 \\
\hline & $(-0.47)$ & $(-0.25)$ & $(-0.11)$ \\
\hline \multirow[t]{2}{*}{ Amount of investment (In) } & 0.005 & $0.043^{\star *}$ & $0.022^{\star \star}$ \\
\hline & $(-0.22)$ & $(2.44)$ & $(2.47)$ \\
\hline \multirow[t]{2}{*}{ Churning rate } & $4.828^{\star \star \star}$ & $1.071^{*}$ & $0.572^{*}$ \\
\hline & $(4.21)$ & $(1.86)$ & $(1.91)$ \\
\hline \multirow[t]{2}{*}{ Share of part-time employees } & -1.100 & $-0.840 * \star$ & $-0.406^{\star \star}$ \\
\hline & $(-1.22)$ & $(2.34)$ & $(2.18)$ \\
\hline \multirow[t]{2}{*}{ Overtime (dummy) } & 0.044 & 0.046 & 0.021 \\
\hline & $(-0.19)$ & $(-0.33)$ & $(-0.28)$ \\
\hline \multirow[t]{2}{*}{ Collective agreements (dummy) } & 0.085 & $0.312^{\star *}$ & $0.157^{* *}$ \\
\hline & $(-0.32)$ & $(2.31)$ & $(2.21)$ \\
\hline \multirow[t]{2}{*}{ Works council (dummy) } & 0.747 & $0.799 * \star \star$ & $0.39 * \star \star$ \\
\hline & $(-1.44)$ & $(5.17)$ & $(4.71)$ \\
\hline \multirow[t]{2}{*}{ New operating units incorporated (dummy) } & $-0.520 *$ & -0.315 & -0.176 \\
\hline & $(1.77)$ & $(-1.27)$ & $(-1.26)$ \\
\hline \multirow[t]{2}{*}{$\begin{array}{l}\text { Operating units have been spun off / hived off / } \\
\text { closed (dummy) }\end{array}$} & -0.098 & -0.024 & -0.014 \\
\hline & $(-0.46)$ & $(-0.13)$ & $(-0.14)$ \\
\hline \multirow[t]{2}{*}{$\begin{array}{l}\text { Consensual termination of employment relationships } \\
\text { (dummy) }\end{array}$} & 0.181 & $0.269 * *$ & $0.175^{\star \star \star}$ \\
\hline & $(-1.25)$ & $(2.30)$ & $(2.59)$ \\
\hline \multirow[t]{2}{*}{ Limited company (dummy) } & -0.333 & $-0.314^{\star *}$ & $-0.205^{\star \star *}$ \\
\hline & $(-1.12)$ & $(2.17)$ & $(2.67)$ \\
\hline \multirow[t]{2}{*}{ Firm size (In) } & $1.210^{\star \star}$ & $0.915^{\star \star \star}$ & $0.500^{\star * *}$ \\
\hline & $(2.57)$ & $(17.40)$ & $(16.97)$ \\
\hline Industry dummies & No & Yes & Yes \\
\hline \multirow[t]{2}{*}{ Constant } & - & $-7.567^{\star \star \star}$ & $-4.183^{\star \star \star}$ \\
\hline & - & $(14.26)$ & $(14.56)$ \\
\hline $\mathrm{N}$ & 2084 & 11820 & 11820 \\
\hline $\mathrm{n}$ & 521 & 2955 & 2955 \\
\hline Pseudo- $R^{2}$ & 0.01 & 0.01 & 0.01 \\
\hline Hausman test & & & \\
\hline
\end{tabular}

${ }^{*} p<0.1 ;{ }^{* *} p<0.05 ; * * * p<0.01$

Source: IAB establishment panel 2003-2006, own calculations, z values in parentheses 
Table 3: Estimate results for the intensity of early retirement in the firm, FE/RE negative binomial regression

\begin{tabular}{|c|c|c|}
\hline Variable & FE-NBReg & RE-NBReg \\
\hline \multirow[t]{2}{*}{ Rate of employment growth } & $-0.923^{\star \star \star}$ & $-1.319^{\star \star \star}$ \\
\hline & (2.65) & (4.96) \\
\hline \multirow{2}{*}{ Low profit situation (dummy) } & -0.102 & -0.073 \\
\hline & $(-1.15)$ & $(-1.02)$ \\
\hline \multirow[t]{2}{*}{ Amount of investment (In) } & 0.016 & $0.036^{\star \star \star}$ \\
\hline & $(-0.90)$ & (2.63) \\
\hline \multirow[t]{2}{*}{ Churning rate } & $4.051^{\star \star \star}$ & $1.051^{\star \star}$ \\
\hline & (4.41) & $(2.37)$ \\
\hline \multirow{2}{*}{ Share of part-time employees } & -0.293 & $-0.640^{\star \star}$ \\
\hline & $(-0.57)$ & $(2.31)$ \\
\hline \multirow[t]{2}{*}{ Overtime (dummy) } & 0.006 & 0.017 \\
\hline & $(-0.04)$ & $(-0.17)$ \\
\hline \multirow[t]{2}{*}{ Collective agreements (dummy) } & -0.094 & $0.284^{\star \star \star}$ \\
\hline & $(-0.49)$ & $(2.63)$ \\
\hline \multirow[t]{2}{*}{ Works council (dummy) } & 0.141 & $0.816^{\star \star \star *}$ \\
\hline & $(-0.47)$ & $(6.55)$ \\
\hline \multirow[t]{2}{*}{ New operating units incorporated (dummy) } & -0.091 & 0.140 \\
\hline & $(-0.52)$ & $(-1.07)$ \\
\hline \multirow[t]{2}{*}{$\begin{array}{l}\text { Operating units have been spun off / hived off / } \\
\text { closed (dummy) }\end{array}$} & -0.065 & -0.033 \\
\hline & $(-0.54)$ & $(-0.33)$ \\
\hline \multirow[t]{2}{*}{$\begin{array}{l}\text { Consensual termination of employment relationships } \\
\text { (dummy) }\end{array}$} & $0.152^{*}$ & $0.148^{* *}$ \\
\hline & $(1.76)$ & $(1.98)$ \\
\hline \multirow[t]{2}{*}{ Limited company (dummy) } & $-0.569 * * *$ & $-0.250^{\star *}$ \\
\hline & (3.87) & $(2.50)$ \\
\hline \multirow[t]{2}{*}{ Firm size $(\ln )$} & $0.197^{* \star *}$ & $0.716^{\star \star \star}$ \\
\hline & $(2.94)$ & $(21.30)$ \\
\hline Industry dummies & No & Yes \\
\hline \multirow[t]{2}{*}{ Constant } & $-1.609^{* * *}$ & $-6.266^{\star * *}$ \\
\hline & $(3.15)$ & $(15.41)$ \\
\hline $\mathrm{N}$ & 2312 & 11820 \\
\hline $\mathrm{n}$ & 578 & 2955 \\
\hline Pseudo- $R^{2}$ & 0.13 & 0.09 \\
\hline Hausman test & & $21^{\star \star \star}$ \\
\hline
\end{tabular}

${ }^{*} p<0.1 ;{ }^{* *} p<0.05 ; * \star * x<0.01$

Source: IAB establishment panel 2003-2006, own calculations, $z$ values in parentheses 